\title{
Acute toxicity of lead nitrate to red swamp crayfish, Procambarus clarkii
}

\author{
A. Balarezo \& P. B. Tchounwou \\ Environmental Toxicology Research Laboratory, \\ NIH-RCMI Center for Environmental Health, College of Science, \\ Engineering and Technology, Jackson State University, USA
}

\begin{abstract}
Red crayfish, Procambarus clarkii, is widely farmed in the southern states of Louisiana and Texas. It is the most valuable of commercial crayfish species in the United States, where it is considered a delicacy. In recent years, its availability has decreased due to environmental contamination by toxic chemicals including lead. In the present study, we conducted a ninety-six-hour static renewal bioassay to assess the acute toxicity of lead as $\mathrm{Pb}\left(\mathrm{NO}_{3}\right)_{2}$ to adult red swamp crayfish. Study results indicated that $\mathrm{Pb}\left(\mathrm{NO}_{3}\right)_{2}$ is toxic to $P$. clarkii, and its toxicity is both time- and concentration-dependent. The 96-hr $\mathrm{LC}_{50}$ was computed to be $3.95 \mathrm{~g} / \mathrm{L}$. During experimentation, erratic behaviors such as restlessness, loss of balance, air gulping, and convulsion were observed in leadexposed crayfish. Findings from this study have provided a scientific basis for designing subsequent experiments to assess the chronic exposure and biomarkers of lead-induced toxicity in P. clarkii.
\end{abstract}

Keywords: red swamp crayfish, lead nitrate, acute toxicity.

\section{Introduction}

Lead $(\mathrm{Pb})$ is a ubiquitous metal that exists in several oxidation states $(0, \mathrm{I}, \mathrm{II}$, and IV). However, $\mathrm{Pb}^{2+}$ is the most stable, available, and suspected of being accumulated by aquatic organisms. The overall concentration of $\mathrm{Pb}$ in the continental crust is estimated to be 20 ppm dry matter. It is number 35 most abundant element in nature. Background levels in the top soil vary between 10 to $70 \mathrm{ppm}$; levels in surface water are generally bellow $0.01 \mathrm{ppm}$, but levels up to $1 \mathrm{ppm}$ can be expected inn contaminated areas with soft waters; in ocean water 
is about $0.0027 \mathrm{ppb}$. In U.S. sediments it is about $9-35 \mathrm{ppm}$, and about 4-700 ppm in soils [1-3].

$\mathrm{Pb}$ enters the aquatic environment through erosion and leaching from soil, dust fallout, combustion of fossil fuels, industrial water discharges, runoff and fallout deposits from streets and other surfaces as well as precipitation. $\mathrm{Pb}$ is known to accumulate in fish tissues, including bone, gills, kidneys, liver, and scales. Its toxicity is influenced by fish life stage, water $\mathrm{pH}$, and hardness, and the presence of organic materials [4-7].

The use of $\mathrm{Pb}$ has resulted in increased levels in soil, water, and air; $\mathrm{Pb}$ atmospheric concentrations as high as $50 \mathrm{pg} / \mathrm{m}^{3}$ has been found in industrialized regions [8]. In addition, areas next to mining activities may be exposed to high emission levels. As $\mathrm{Pb}$ particles (dust) may be transported via air, an individual source of emission may pollute areas located far away from its source. Industrial use of $\mathrm{Pb}$ may comprise mining, smelting, and processing, $\mathrm{Pb}$ - containing water pipes, plumbing solders, alloys, pigments, batteries, and ceramics and glassware $[7,8]$.

Historically, $\mathrm{Pb}$ in solders and alloys for water drinking pipes and as additive to gasoline have been the major source of environmental pollution, and animal and human exposure. In recognition of the toxic effects of $\mathrm{Pb}$, most countries have phased out the use of $\mathrm{Pb}-\mathrm{E}_{4}$ in the fossil fuel energy industry. However, the emission of $\mathrm{Pb}$ from waste incinerators and waste disposals still remains. Accidental exposure of animals may also result from $\mathrm{Pb}$ shuts, disposed linoleum, and from $\mathrm{Pb}$ containing ornaments, toys, and pigments. Particularly, intoxications of animals resulting from disposed batteries ingestion has been reported [8].

$\mathrm{Pb}$ accumulation in soils and surface water depends on many factors including $\mathrm{pH}$, mineral composition, and type and amount of organic material. $\mathrm{Pb}$ in soils is transferred to food crops. Roots usually contain more $\mathrm{Pb}$ than stems and leaves, while seeds and fruits contain the lowest concentrations [9].

Several studies have demonstrated that aquatic invertebrates exhibit various degrees of sensitivity to lead toxicity [10-17]. These invertebrates include the American red crayfish, Procambarus clarkii, which is native to the Louisiana marshes (USA) [18, 19]. It is commercially farmed and harvested as a very important food source, both to fishing industries and to recreational and subsistence fishermen in Louisiana and other southern states [20]. Additionally, it has been reported that crayfish are being fished commercially for consumption without adequate protection to human health [12]. They constitute a commercially valuable natural renewable resource [21]. Also, they live in a wide range of environmental conditions that include highly polluted waters resulting in high resistance to heavy metals $[13,18,22]$. Hence, it is important to investigate the sensitivity of this valuable ecologic resource to toxic chemicals. The present study was designed to determine the acute toxicity of lead to red swamp crayfish in order to gather the necessary scientific information for the conduct of subsequent chronic experiments.

\section{Materials and methods}

Test organisms (mean body weight 15.3-28.5 g) were obtained from a local business supplier in Jackson, MS. They were initially declawed to preclude 
cannibalism and predation. Prior to experimentation, specimens were acclimatized at laboratory conditions for 2 weeks period, into several 50 gallon glass aquaria filled with 20 gallons of dechlorinated tap water. Crayfish were fed sinking waffles fish food ad libitum once every other day to avoid water fouling and reduce feces generation. Feeding was stopped $24 \mathrm{hr}$ prior to testing and during testing.

Ninety-six hours static renewal bioassay was conducted according to standard testing protocols. Range-finding, subsequent and definitive experiments were conducted according to 8910 American Public Health Association (APHA) standardized procedures [23]. A completely randomized design with 6 treatments $\left[0,2,4,6,8\right.$, and $\left.10 \mathrm{~g} / \mathrm{L} \mathrm{Pb}\left(\mathrm{NO}_{3}\right)_{2}\right]$ was deployed with three replicates per concentration and 4 organisms in each replicate. Tests were carried out in 2gallon glass aquaria filled with 4 liters of $\mathrm{Pb}$-solution at different concentrations. Four randomly sorted crayfish were placed in each of the 6 test chambers and their replicates. The bioassays included a total of 18 experimental units carried out during 96-h period. The tests were repeated two times to ensure reproducibility. No-aeration, no-feeding, but daily renewal of freshly prepared and aerated solutions were maintained during the $96-\mathrm{h}$ testing period.

Lethality was observed every $2 \mathrm{hr}$ for the first 12 hours of exposure, and then after every $24 \mathrm{hr}$. Dead crayfish were immediately removed to keep water quality. The percentages of mortality or viability at each $24 \mathrm{hr}$ of exposure were calculated. To determine the $\mathrm{LC}_{50}$, a linear correlation between crayfish mortality and decimal logarithm of $\mathrm{Pb}$-concentration was established; the correlation equation and regression coefficient, $\mathrm{R}^{2}$, were obtained.

During experimentation, basic water quality parameters including temperature, $\mathrm{pH}$, dissolved oxygen, hardness and alkalinity were analyzed following standard protocols [23]. A photoperiod of $11 \mathrm{~h}$ light and $13 \mathrm{~h}$ darkness was maintained.

\section{Results}

The physicochemical characteristics of the laboratory water, supplied for all the bioassays carried out in this research, were in the following range: $\mathrm{pH}=6.8-7.2$; dissolved oxygen $=7.5-8.3 \mathrm{mg} / \mathrm{L}$; temperature: $18-22^{\circ} \mathrm{C}$, alkalinity $10-20 \mathrm{mg} / \mathrm{L}$ as $\mathrm{CaCO}_{3}$, and hardness $12-15 \mathrm{mg} / \mathrm{L}$ as $\mathrm{CaCO}_{3}$.

Acute exposure to lethal concentrations of $\mathrm{Pb}$ resulted in noticeable impact on crayfish viability. The mean values of viability of crayfish exposed to various concentrations of $\mathrm{Pb}^{2+}$ for $24,48,72$, and $96 \mathrm{hr}$ are presented in Figure 1. It was observed that during the exposure period, all crayfish in the control group survived. Within the first $24 \mathrm{hr}$ of exposure, no crayfish mortality was observed for all $\mathrm{Pb}$-concentrations $(2,4,6,8$, and $10 \mathrm{~g} / \mathrm{L})$ assayed. After $48 \mathrm{hr}$ of exposure the percentage of crayfish mortality markedly increased from 25 to $87 \%$. After $72 \mathrm{hr}$ of exposure, $100 \%$ crayfish mortality was observed for the three higher $\mathrm{Pb}$-concentrations $(6,8$, and $10 \mathrm{~g} / \mathrm{L})$. After $96 \mathrm{hr}$ exposure, viability was only noticed for the $2 \mathrm{~g} / \mathrm{L} \mathrm{Pb}$-bioassays. In addition, results demonstrated that viability of crayfish and concentration of $\mathrm{Pb}$ in the exposure medium were negatively related; in other words, mortality rates of the crayfish increased with increasing in $\mathrm{Pb}$-concentration and exposure period. 
104 Environmental Toxicology III

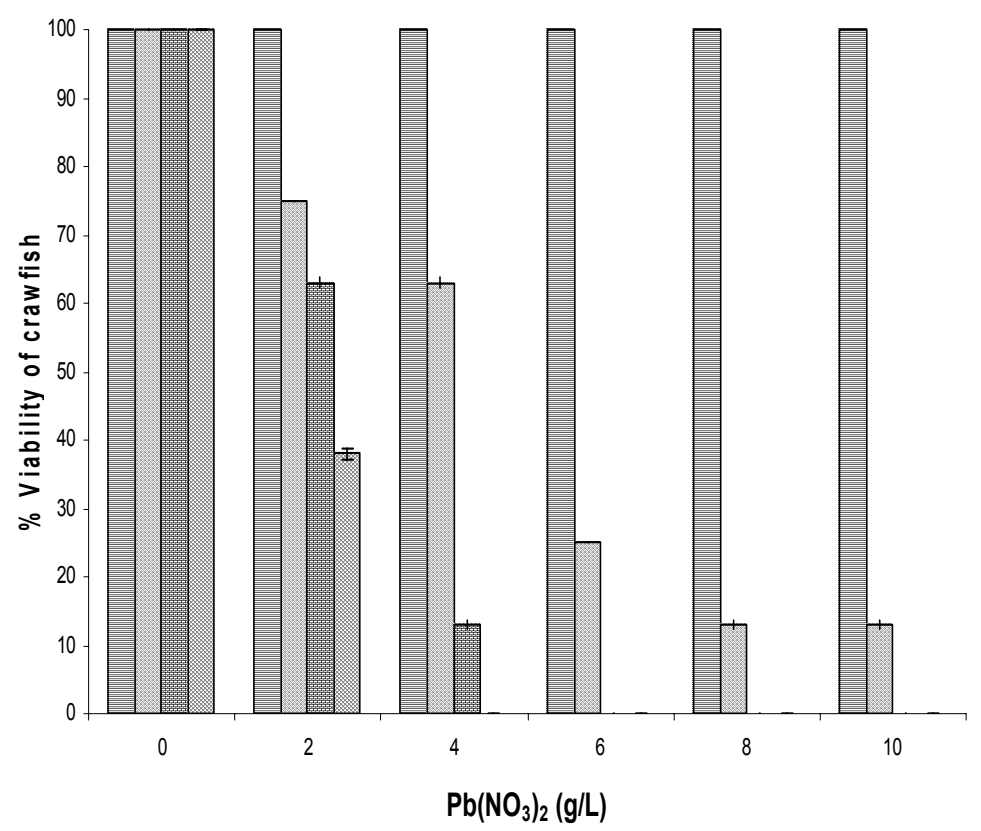

Figure 1: $\quad$ Effect of $\mathrm{Pb}\left(\mathrm{NO}_{3}\right)_{2}$ on the viability of adult Procambarus clarkii at 24, 48, 72, and $96 \mathrm{hr}$ of exposure.

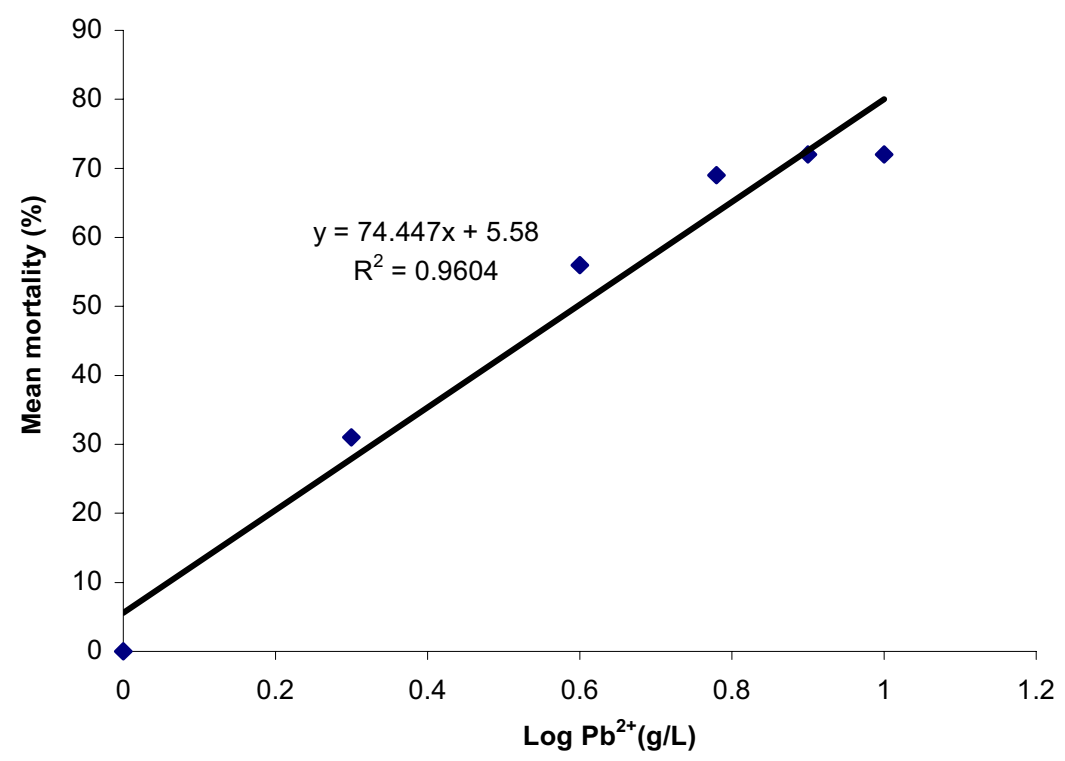

Figure 2: $\quad$ Correlation of crayfish mortality $(\%)$ and $\mathrm{Pb}$-concentration $(\mathrm{g} / \mathrm{L})$ at 96-hr exposure. 
During experimentation, lead-exposed crayfish exhibited various behavioral patterns before death occurred; restlessness, motionless, loss of balance (i.e. over turning), air gulping and convulsion were frequently observed. However, such responses were minimal in the groups exposed to $2.0 \mathrm{~g} / \mathrm{L} \mathrm{Pb}\left(\mathrm{NO}_{3}\right)_{2}$ and none at all in controls.

Clearly, both time- and concentration-response relationships were observed in these bioassays. Figure 2 shows the regression analysis of the relationship between crayfish mortality and $\mathrm{Pb}\left(\mathrm{NO}_{3}\right)_{2}$ concentration after $96 \mathrm{hr}$ of exposure. From the regression curve, a $96-\mathrm{hr} \mathrm{LC}_{50}$ value was calculated to be $3.95 \mathrm{~g} / \mathrm{L}$.

\section{Discussion}

This study demonstrated that lead, as $\mathrm{Pb}\left(\mathrm{NO}_{3}\right)_{2}$ is toxic to crayfish, and its toxicity in time- and concentration-dependent. Upon $96 \mathrm{hr}$ of exposure the $\mathrm{LC}_{50}$ was $3.95 \mathrm{~g} / \mathrm{L}$, which is considerably higher than the $751.57 \mathrm{mg} / \mathrm{L}$ reported by Naqvi and Howell [15] from their investigation of the effect of lead nitrate on the fecundity of juvenile Louisiana swamp crayfish (Procambarus clarkii). The major possible reasons for this marked difference in values of $\mathrm{LC}_{50}$ could be (a) organisms source and age: laboratory-raised versus farm-raised crayfish, and juvenile versus adult crayfish; (b) water quality of bioassays: aged tap versus synthetic. The water quality used in our research, although not aged tap, was acceptable according to EPA-807-8720 (Toxicity test procedures for crustaceans); and (c) the actual $\mathrm{Pb}$-concentration derived from nitrate salt [100 $\mathrm{mg} / \mathrm{L}$ as $\left.\mathrm{Pb}\left(\mathrm{NO}_{3}\right)_{2}=16.84 \mathrm{mg} / \mathrm{L} \mathrm{Pb}\right]$ versus $60.72 \mathrm{mg} / \mathrm{L}$ of $\mathrm{Pb}$ for the same $\mathrm{Pb}\left(\mathrm{NO}_{3}\right)_{2}$ concentration. Age and size of specimens have been reported to influence to the extent of masking observed trends of bioconcentration [24]. In addition, in the present research $100 \%$ crayfish viability was observed within the $24 \mathrm{hr}$ exposure to $2 \mathrm{~g} / \mathrm{L}$, compared to $8 \%$ mortality at $1 \mathrm{~g} / \mathrm{L} \mathrm{Pb}\left(\mathrm{NO}_{3}\right)_{2}$ reported by Naqvi and Howell [15].

Erratic behavior such as restlessness, loss of balance, air gulping, and convulsion observed during experimentation are in agreement with earlier reports by Anderson [10] and Naqvi and Howell [14, 15]. These behavioral responses are indications of toxicity due to nervous disorders and insufficient gaseous exchange across the gill epithelia they mentioned. The toxic manifestation would be consistent with the inhibition of the enzyme acetylcholinesterase, resulting in death by paralysis of muscles of respiration and/or depression of the respiratory center [25]. Other studies have reported that that $\mathrm{Pb}$ is more toxic at low $\mathrm{pH}[8,26]$.

\section{Acknowledgements}

This research was financially supported in part by a grant from the National Institutes of Health (No. 2G12RR013459), and in part by a grant from the National Oceanic and Atmospheric Administration - NOAA Grant No. NA17AE1626, Subcontract No. 27-0629-017 to Jackson State University. 


\section{References}

[1] Galvin R.M. Occurrence of metals in water: An overview. Water $S A, 22$, pp. 7-18, 1996.

[2] WHO-IPCS. Inorganic lead, Environmental Health Criteria 165. World Health Organization, Geneva, Switzerland. 1995.

[3] Tchounwou P.B. A.A. Siddig \& M.L. Marian. Post-remediation monitoring for soil, sediment, and water contamination by lead from a controlled superfund site in Mississippi. In: Environmental Toxicology and Risk Assessment: Eighth Volume, ASTM STP 1381. F.T. Price, K.V. Brix, and N.K. Lane, Eds. American Society for Testing and Materials, West Conshohocken, PA. pp. 16-32, 2000.

[4] Hellawell J.M. Biological Indicators of Freshwater Pollution and Environmental Management. Elsevier Applied Science Publishers. London. 1986.

[5] Moore J.W.W. \& S. Ramamoorthy. Heavy metals in natural waters, In: Applied Monitoring and Impact Assessment. Springer Verlag, N.Y., 1984.

[6] Merlini M. \& G. Pozzi. Lead and fresh water fishes: Part 2-Ionic lead accumulation. Environ. Pollut. 13, pp. 119-126, 1997.

[7] WHO-IPCS. Lead, Environmental Criteria 85. World Health Organization, Geneva, Switzerland. 1989.

[8] ATSDR (Agency for Toxic Substances and Diseases Registry). Toxicological Profile for Lead (Update). Center for the Disease Control and Prevention, Agency for Toxic Substances and Disease Registry, Atlanta, GA. 1999.

[9] Davies D.J., J.M. Watt, \& I. Thornton. Lead levels in Birmingham dust and soils. Sci. Total. Environ. 67, pp. 177-185, 1987.

[10] Anderson R.V. The effect of lead on oxygen uptake in the crayfish, Orconectes virilis (HAGEN). Bull. Environ. Contam. Toxicol. 2, pp. 394400, 1078.

[11] Tulasi S. J., R. Yasmeen, C. P. Reddy \& J.V. R. Rao. Lead uptake and lead loss in the freshwater field crab, Barytelphusa guerini, on exposure to organic and inorganic lead, Bull. Environ. Contam. Toxicol. 39, pp. 63-68, 1987.

[12] Pastor A., J. Medina, J. Del Ramo, A. Torreblanca, J. Diaz-Mayans \& F. Hernandez. Determination of lead in treated crayfish Procambarus clarkii: accumulation in different tissues. Bull. Environ. Contam. Toxicol. 41, pp. 412-418, 1988.

[13] Martinez M., A. Torreblanca, J. Del Ramo, \& J. Diaz-Mayans. Effects of sublethal exposure of lead on levels of energetic compounds in Procambarus clarkii (Girad, 1852), Bull. Environ. Contam. Toxicol. 52, pp. 729-733, 1994.

[14] Naqvi, S.M. \& R.D. Howell. Cadmium and lead uptake by red swamp crayfish (Procambarus clarkii) of Louisiana. Bull. Environ. Contam. Toxicol. 51, pp. 296-302, 1993. 
[15] Naqvi S. M. \& R. D. Howell. Toxicity of cadmium and lead to juvenile red swamp crayfish (Procambarus clarkii), and effects on fecundity of adults. Bull. Environ. Contam. Toxicol. 51, pp. 303-308, 1993.

[16] Devi M. \& M. Fingerman. Inhibition of acetylcholinesterase activity in the central nervous system of the red swamp crayfish, Procambarus clarkii by mercury, cadmium, and lead. Bull. Environ. Contam. Toxicol. 55, pp. 746$750,1995$.

[17] Tungare S. M. \& A. D. Sawant. Lead and cadmium in selected species of shrimp around the Mumbai coast, India. Bull. Environ. Contam. Toxicol. 68, pp. 455-462, 2002.

[18] Abdelghani A. A., Y.V. Pramar, T.K. Mandal, P.B. Tchounwou, \& L. R. Heyer,. Levels and toxicities of selected inorganic and organic contaminants in a swamp environment. J. Environ. Sci. \& Health, B30 (5), pp. 717-731, 1995.

[19] Torreblanca A., J. Del Ramo, \& J. Diaz-Mayans. Effects of cadmium on the biochemical composition of freshwater crayfish Procambarus clarkii, (Girard, 1852). Bull. Environ. Contam. Toxicol. 47, pp. 933-938, 1991.

[20] Green R.M. \& A. Abdelghani. 2004. Toxicity of a 2,4dichorophenoxyacetic acid and monosodium methanearsonate to the red swamp crayfish, Procambarus clarkii. Int. J. Environ. Res. Public Health 1, pp. 35-38, 2004.

[21] Naqvi S. M. I. Devalraju, \& N. H. Naqvi. 1998. Copper bioaccumulation by red swamp crayfish, Procambarus clarkii, Bull. Environ. Contam. Toxicol. 61, pp. 65-71, 1998.

[22] Torreblanca A., J. Del Ramo \& J. Diaz-Mayans. 1989. Gill ATPase activity in Procambarus clarkii as an indicator of heavy metal pollution. Bull. Environ. Contam. Toxicol. 42, pp. 829-834, 1989.

[23] APHA (American Public Health Association). Standard Methods for Examination of Water and Wastewater. Editors: S. Clesceri, A. E. Greenberg \& A. D. Eaton, 20th Edition, Washington, DC. 1998.

[24] Vinikour W.S. R.M. Goldstein \& R.V. Anderson. Bioaccumulation patterns of $\mathrm{Zn}, \mathrm{Cu}, \mathrm{Cd}$, and $\mathrm{Pb}$ in selected fish species from the Fox River, Illinois. Bull. Environ. Contam. Toxicol., 24, pp. 727-734, 1980.

[25] Cearly J.E. \& R.L. Coleman. Cadmium toxicity in largemouth bass and bluegill. Bull. Environ. Contam. Toxicol. 11, pp.146, 1974.

[26] Schubawer-Berigan M.K., J.R. Dicken, P.D. Monson, \& G.T. Ankly. pHdependent toxicity of $\mathrm{Cd}, \mathrm{Cu}, \mathrm{Ni}, \mathrm{Pb}$ and $\mathrm{Zn}$ to Ceriodaphnia dubia, pimaphales promelas, Hyalella azteca, and Lumbriculus variegates. Environ. Toxicol. Chem. 12, pp. 1261-1266, 1993. 